\title{
Analysis of Information Technology Readiness in Furniture Business in Indonesia
}

\author{
U Chotijah" ${ }^{* 1}$ F Retrialisca*2 \\ ${ }^{1}$ Department of Informatics, Faculty of Engineering, Universitas Muhammadiyah Gresik, \\ Indonesia \\ ${ }^{2}$ Information Systems Study Program, Department of Engineering, Universitas Airlangga, \\ Surabaya, Indonesia
}

E-mail: umi.chotijah@umg.ac.id ${ }^{1}$, fitriretrialisca@vokasi.unair.ac.id ${ }^{2}$

Submitted: 30 June 2020, revised: 19 August 2020, accepted: 20 August 2020

\begin{abstract}
Abstrak. Adopsi teknologi informasi (TI) dapat dinilai dari perspektif kesiapan pengguna. Penelitian ini mengkaji tingkat kesiapan Usaha Mikro Kecil Menengah (UMKM) di sektor furnitur dalam mengadopsi TI. Desain dan model penelitian dikembangkan dengan menggunakan Technology Acceptance Model (TAM) dan Technology Readiness Index (TRI). Pengambilan sampel yang digunakan dalam penelitian ini adalah nonprobability procedure dengan teknik purposive sampling. Pengumpulan data dilakukan dengan metode survei kuesioner dan dianalisis menggunakan metode Partial Least Square (PLS). Secara umum, hasil penelitian menunjukkan bahwa UKM sektor furnitur di Pulau Jawa sudah siap mengadopsi TI. Namun temuan penelitian juga menunjukkan bahwa persepsi ketidaknyamanan dan ketidakamanan merupakan isu utama yang berpotensi menghambat adopsi TI oleh UKM sektor furnitur. Implikasi bagi pemangku kepentingan dan penelitian empiris dibahas lebih lanjut.
\end{abstract}

Kata Kunci: indeks kesiapan teknologi; model penerimaan teknologi, UMKM, furnitur

\begin{abstract}
Adoption of information technology (IT) can be assessed from the perspective of user readiness. This study examines the level of readiness of the Micro, Small and Medium Enterprises (MSME) of furniture sector in adopting IT. The design and research model are developed using the Technology Acceptance Model (TAM) and the Technology Readiness Index (TRI). The sampling used in this study is a non-probability procedure with a purposive sampling technique. The data is collected using questionnaire survey method and analyzed using the Partial Least Square (PLS) method. In general, the research findings indicate that the furniture sector SMEs in Java are prepared to adopt IT. However, research findings also indicate that the perception of discomfort and insecurity is the major issue that potentially hinders the IT adoption by the furniture sector SMEs. The implications for stakeholders and empirical research are discussed further.
\end{abstract}

Keywords: technology readiness index; technology acceptance model; MSME; furniture 


\section{Introduction}

Indonesia as a developing country, most of the economy is supported by Micro, Small and Medium Enterprises (MSMEs). The data collecting from the Central Bureau of Statistics (BPS) reports that $90 \%-95 \%$ of businesses in Indonesia are listed as small and medium-sized enterprises. This indicates that Indonesia's economic development has been driven and controlled by SMEs activities. MSMEs have also demonstrated the sustainability of their companies in the midst of a market crisis. It is because MSMEs have a large market in the country and do not rely on the financial services sector.

In the face of increasingly intense market rivalry, technology has become one of the methods to encourage the productivity of companies. This is certainly quickly simple to do by companies that have necessary resources, but for MSMEs the use of technology may not have been a priority in business development. Previous research states that information technology is one of the holistic models of Business Process Management Maturity (BPMM) as a diagnostic tool to enable identification of business process deficiencies in the company [1]. By integrating the right Information and Communication Technology (ICT) applications with business processes at the right time, ICT can help MSMEs increase competitive ability and develop the ability to innovate, to create and to share knowledge, which is very important to compete and survive in a knowledgeable society [2]. Despite the determinants of the maturity level of MSME business processes, MSMEs in Indonesia are very far from implementing IT [3]. The weakness of MSMEs in improving business capability is very complex, starting from the lack of capital, managerial skills, operating skills in organizing, and marketing [4].

In terms of technology use, ICT adaptation is not a priority since there is only $58.6 \%$ of MSMEs have adopted computer technology to support their business process activities [5]. The difficulty in applying industrial technology 4.0 is caused by the lack of workers, the beyond-reach industry that not in terms of products and production, and in capability to invest new technology [6].

The development of MSME in entering industry 4.0 requires a readiness of the actors or owners of MSME. Assessing the readiness to adopt new innovations is an important prerequisite for developing and following market developments. This shows that ICT plays an important role in the world of business and industry [7].

This study aims to examine the readiness of the MSME furniture sector in Indonesia in adopting IT. This research is important for several reasons. Firstly, the previous empirical studies are more concentrated in discussing implementation while the empirical research that examines the determinants of IT adoption at MSMEs is relatively limited [8]. In fact, a study of the determinants of IT adoption and readiness provides strategic information for the government in formulating MSME development policies. Second, the previous empirical studies tend to study in the context of large companies so that their findings cannot be generalized in the context of MSMEs, because the two research contexts have fundamental differences in company size, economies of scale, managerial models, types of IT needed, and IT governance systems models. The special feature of MSMEs is the centralized decision structure and the central role of the leadership which reinforces the notion that the characteristics of the leader play a major role in the decision process for adopting IT. Another characteristic of small businesses related to IT adoption is the low level of IT knowledge and technical skills possessed by leaders and employees, which later becomes an obstacle for MSMEs in adopting IT. The low readiness and ability to operate a computer also allows for the emergence of perceptions about the many difficulties that will be faced in adopting computer technology to run a business.

In the discussion about the acceptance of information systems/new technologies, the theory of acceptance model ( TAM) introduced by Davis (1989) notes that the use of the system (system usage) is affected by the interest in the use of the system (behavioral intention). Interest in using a system is influenced by user perceptions (beliefs) which are further divided into two, namely perception of system usefulness (perceived of usefulness) and perceived ease of use. Individual characteristics become one of the center of attention in determining factors that influence a person's acceptance to new information/technology systems. One of them is the readiness of individuals to use technology in 
general. This readiness is measured through an instrument, the Technology Readiness Index (TRI) [9]. TRI has four dimensions consisting of: optimism, innovation, discomfort, and insecurity.

Based on the description stated above, this study combining the concept of Technology Acceptance Model (TAM) and Technology Readiness Index (TRI) to determine the impact of Technology Readiness on the perceived usefulness of the system (perceived of usefulness) and perceived ease of use by individuals or MSME owners. Subsequently, the interest in using/adopting (behavioral intention) computer technology to support business processes in MSME furniture sector in Indonesia increases.

\section{Literature}

\subsection{Information Technology Adoption Model}

There are many theories used in Information Systems research. The author is only interested in theories about technology adoption. The most widely used theory is the Technology Acceptance Model (TAM) [10] [11] [12], Theory of Planned Behavior (TPB) [13] [14], Unified Theory of Acceptance and Use of Technology (UTAUT) [15], DOI [16], and the TOE framework [17]. The author will only develop DOI, and especially the TOE framework, because DOI and TOE are the only ones that exist at the company level. TAM, TPB and UTAUT model are at the individual level.

\subsection{Technology Readiness Index (TRI)}

There are differences in people's tendency to use technology. Rogers divided people into five groups that explained their character; from innovator to slow [16]. The technology readiness index (TRI) is a framework related to technology in general. The different characteristics between people and their beliefs about different aspects of technology are not the same. The relative strength of each trait indicates one's openness to technology. TRI thus reflects a set of beliefs about technology but is not an indicator of one's competence in using it.

TRI has four constructs: two constructs which are motivators, and the other two constructs are obstacles. The four components include:

- Motivator:

Optimism - the general belief that technology and innovation have positive benefits

Innovative - inherent tendency to want to experiment, learn and talk about technology

- Inhibitors:

Discomfort - lack of control over technology

Insecurity - the belief that technology can have a negative impact on users and society

\subsection{Technology Acceptance Model (TAM)}

Technology Acceptance Model (TAM) is a model that can be used to evaluate factors that affect the acceptance of a system. There are three variables that have an effect on the use of the device [10]:

1) Perceived Usefulness: A level where someone believes that using the system can improve work performance

2) Perceived Ease of Use: A level where someone believes that using the system does not need to bother

3) Intention To Use: Behavioral tendency to use a technology

The three factors listed above can be used as variables in the research to decide how the user embraces an information system that is being designed or running.

\section{Methods}

This research is a comparative causal study that aims to explain the relationship between variables studied. This study discusses the influence of technology readiness on the perception of system usefulness (perceived of usefulness) and perception ease of use of the system (perceived ease of use) towards the adoption of computer technology by MSMEs in Indonesia. 
This research is conducted using survey method. The population of this study are all MSMEs in the furniture sector registered at BPS (Central Statistics Agency) in 2012 with a total population of seven companies.

We use purposive sampling as the sampling technique. Purposive sampling technique is the technique of identifying the sample with any assumptions [18]. The criteria used to assess the sample of this analysis are MSMEs in the furniture sector registered at BPS.

To test the proposed hypothesis, the researcher used the following model:

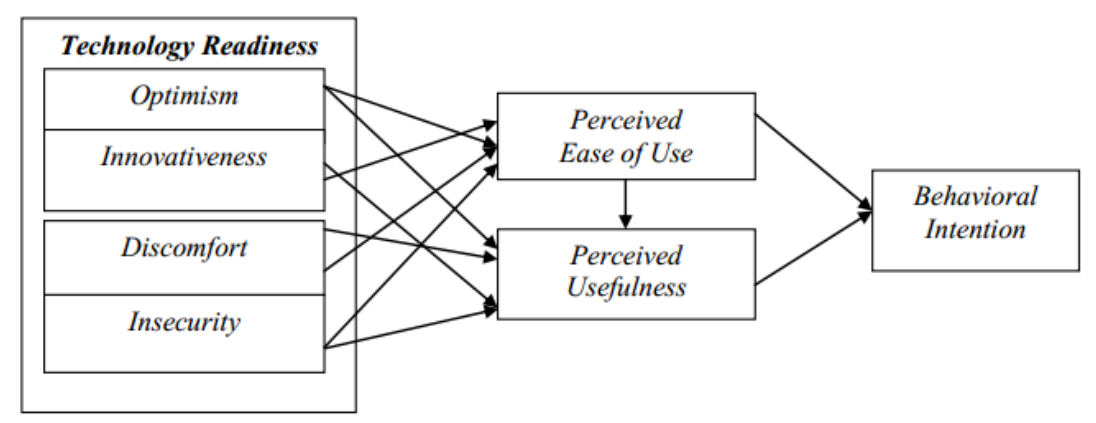

Figure 1. Research Model of Technology Readiness

\subsection{Research Instruments}

For data collection by questionnaire, this study uses a nominal scale 1-7 with strongly disagree for value 1 and strongly agree for value 7 . Respondents are free to determine the value of each question without solving/giving criteria that have been determined. The omission of these criteria aims to avoid the opinion bias given by respondents due to the tendency to give an answer with safe value. The instrument grids are presented in the following Table 1:

Table 1. Questionnaire

\begin{tabular}{|c|c|c|c|}
\hline Variable & Indicator & Item & Source \\
\hline \multirow[t]{4}{*}{ Technology Readiness } & Optimism & $1^{*}, 2,3,4,5,6,7,8^{*}, 9^{*}, 10$ & \multirow[t]{4}{*}{ Walczuch et al (2007) } \\
\hline & Innovativeness & $11,12^{*}, 13,14,15,16,17$ & \\
\hline & Discomfort & $\begin{array}{l}18,19^{*}, 20^{*}, 21^{*}, 22^{*}, 23^{*}, 24^{*}, \\
25^{*}, 26^{*}, 27^{*}\end{array}$ & \\
\hline & Insecurity & $\begin{array}{l}28^{*}, 29^{*}, 30,31^{*}, 32,33,34,35 \\
36\end{array}$ & \\
\hline Perceived of Usefullness & & $37,38,39,40,41,42$ & Davis (1989) \\
\hline Perceived Ease of Use & & $43,44,45,46^{*}, 47,48$ & Davis (1989) \\
\hline Behavioral of Intention & & $49,50,51$ & \\
\hline
\end{tabular}

*: invalid 


\section{Results}

\subsection{Validity}

Pearson Correlation Product Moment Validity Test uses the principle of correlating or linking each item or problem score with the total score obtained from the respondent's answer to the questionnaire.

From the analysis results obtained correlation values between item scores with total scores. Then the value is compared with the $\mathrm{r}$ table. $\mathrm{R}$ table is sought at the 0.05 significance by 2 -sided test and the amount of data $(\mathrm{n})=7$, then the $\mathrm{r}$ table is 0.754 (see table $\mathrm{r}$ ).

Based on the analysis results obtained correlation values for items 1, 8, 9, 12,20, 21, 22, 23, 24, $25,26,27,28,29,31$, and 46 with values less than 0.754 . Because the correlation coefficients on these items are less than 0.754 , it can be concluded that the items do not correlate significantly with the total score (declared invalid) so they must be excluded or corrected. While in other items the value is more than 0.754 and it can be concluded that the instrument is valid.

\subsection{Reliability}

The reliability test is used to assess the internal accuracy of the measurement instrument. Reliability test shows the consistency and accuracy of a tool in measurement [19].

The following are the results of the analysis conducted in the steps of Reliability Test in SPSS:

\section{Case Processing Summary}

Case Processing Summary

\begin{tabular}{|ll|r|r|}
\hline & \multicolumn{1}{|c|}{$N$} & \multicolumn{1}{|c|}{$\%$} \\
\hline Cases & Valid & 7 & 100.0 \\
& Excluded & & .0 \\
& Total & 7 & 100.0 \\
\hline
\end{tabular}

a. Listwise deletion based on all variables in the procedure.

Figure 2. Case Processing Summary

The overview case analysis table shows the total cases examined and the number of relevant case values.

2. Reliability Statistics

\section{Reliability Statistics}

\begin{tabular}{|c|r|}
\hline $\begin{array}{c}\text { Cronbach's } \\
\text { Alpha }\end{array}$ & N of ltems \\
\hline .549 & 34 \\
\hline
\end{tabular}

Figure 3. Reliability Statistics

The reliability statistics table shows the results of the analysis of the reliability test with Cronbach's Alpha $=0.549$ of 51 variable items. The reliability value of 0.549 is a moderate value. So this questionnaire is said to be consistent (reliable). 
Item-Total Statistics

\begin{tabular}{|c|c|c|c|c|}
\hline & $\begin{array}{l}\text { Scale Mean if } \\
\text { ltem Deleted }\end{array}$ & $\begin{array}{c}\text { Scale } \\
\text { Variance if } \\
\text { Item Deleted }\end{array}$ & $\begin{array}{l}\text { Corrected } \\
\text { Item-Total } \\
\text { Correlation }\end{array}$ & $\begin{array}{l}\text { Cronbach's } \\
\text { Alpha if Item } \\
\text { Deleted }\end{array}$ \\
\hline OPT2 & 173.00 & 120.667 & .704 & .510 \\
\hline OPT3 & 173.14 & 122.476 & .524 & .518 \\
\hline OPT4 & 173.29 & 121.238 & .319 & .522 \\
\hline OPT5 & 173.14 & 128.143 & .074 & .549 \\
\hline OPT6 & 172.71 & 125.238 & .395 & .529 \\
\hline OPT7 & 172.86 & 127.476 & .307 & .536 \\
\hline OPT10 & 173.43 & 118.286 & .430 & .509 \\
\hline INN1 & 175.00 & 103.000 & .539 & .463 \\
\hline INN3 & 175.29 & 113.238 & .427 & .498 \\
\hline INN4 & 175.00 & 110.000 & .502 & .484 \\
\hline INN5 & 174.43 & 118.952 & .190 & .535 \\
\hline INN6 & 174.00 & 121.000 & .149 & .542 \\
\hline INN 7 & 174.57 & 101.619 & .660 & .447 \\
\hline DIs1 & 173.57 & 139.286 & -.306 & .587 \\
\hline INS3 & 175.57 & 145.952 & -.388 & .622 \\
\hline INS5 & 175.43 & 152.619 & -.538 & .638 \\
\hline INS6 & 175.00 & 147.333 & -.434 & .623 \\
\hline INST & 175.00 & 147.333 & -.434 & .623 \\
\hline INS8 & 175.57 & 142.952 & -.358 & .606 \\
\hline INS9 & 175.71 & 144.905 & -.394 & .613 \\
\hline USE1 & 172.14 & 130.810 & .068 & .548 \\
\hline USE2 & 172.14 & 130.810 & .068 & .548 \\
\hline USE3 & 172.14 & 130.810 & .068 & .548 \\
\hline USE4 & 172.14 & 130.810 & .068 & .548 \\
\hline USE5 & 172.29 & 135.238 & -.299 & .564 \\
\hline USE6 & 172.14 & 130.810 & .068 & .548 \\
\hline EASE1 & 172.71 & 123.238 & .528 & .520 \\
\hline EASE2 & 172.71 & 123.238 & .528 & .520 \\
\hline EASE3 & 172.71 & 123.238 & .528 & .520 \\
\hline EASE5 & 173.00 & 110.667 & .683 & .475 \\
\hline EASE6 & 172.86 & 109.143 & .699 & .469 \\
\hline $\mathrm{Bl} 1$ & 173.57 & 114.286 & .436 & .499 \\
\hline $\mathrm{BI} 2$ & 173.14 & 118.143 & .617 & .502 \\
\hline $\mathrm{Bl} 3$ & 172.86 & 116.476 & .562 & .498 \\
\hline
\end{tabular}

Figure 4. Item Total Statistics

Figure 4 shows the change of Cronbach's Alpha value if each item is removed from the questionnaire. This can be used if it is felt that Cronbach's Alpha value is still insufficient for the relevant research. 


\section{Discussion}

In testing the effect of optimism on the perception of technology researchers proposed two hypotheses, namely: H1a: Optimism towards technology has a positive effect on perceived ease of use of technology, and H1b: Optimism on technology has a positive effect on the perception of the benefits of using technology. Both hypotheses are supported by research results. This support shows that individual optimism can encourage someone to adopt a technology. For SMEs, this also has an impact on the company's decision to adopt computer technology. Attitude optimistic that the use of computers in their business activities will be able to provide operational benefits and convenience as well as contribute to operating profits will encourage the implementation of computer technology by MSME actors / owners.

The results of this hypothesis test are in line with research conducted by Walczuch [20] who also has the same conclusions as this study. They also stated that optimism has a fairly strong influence on perception utilization and perception of ease of use of technology.

Effect of Innovativeness on perceptions of technology tested through H2a: Innovativeness on technology has a positive effect on perceptions of ease of use of technology, and $\mathrm{H} 2 \mathrm{~b}$ : Innovativeness on technology has positive effect on the perception of the benefits of using technology. Hypothesis 2a $(\mathrm{H} 2 \mathrm{a})$ is supported by the test results while hypothesis $2 \mathrm{~b}(\mathrm{H} 2 \mathrm{~b})$ is not supported. Support for $\mathrm{H} 2 \mathrm{a}$ is in line with the research of $\mathrm{Yi}$ et al (2006) which shows that high levels of individual innovation support the rate of adoption of a technology. This research shows the level of personal innovation is a strong factor in the perception of ease of technology.

$\mathrm{H} 2 \mathrm{~b}$ stating that a positive relationship between innovativeness and perceived benefits is not supported by the results of tests that have been done. The rejection of this hypothesis can be caused by the majority of respondents engaged in handicraft businesses that have low technological content in running their main business processes. The low content of technology is evidenced by the low use of computer technology (52\%) compared to the number of competitors who also use computer technology (50\%). Thus, the respondents' technological content to run a business does not play a significant role that impacts the perception of the benefits of technology computer to run a business.

Testing the effect of Discomfort on perception of technology is done by proposing two hypotheses, namely: H3a: Discomfort on technology negatively affects the perception of ease of use of technology and H3b: Discomfort on technology does not affect the perception of the benefits of using technology. The test results show that hypothesis $3 \mathrm{a}(\mathrm{H} 3 \mathrm{a})$ is not supported while hypothesis $3 \mathrm{~b}$ (H3b) is supported. Support to the hypothesis is in accordance with the results of the study of Walczuch [20] which shows that people who are less comfortable will have a tendency not to perceive the benefits of using technology.

Test results that show the rejection of hypothesis $3 \mathrm{a}(\mathrm{H} 3 \mathrm{a})$ show a negative relationship, in line with the hypothesis, although it cannot be concluded to have a negative effect because the effect is not significant. This shows that although respondents feel uncomfortable with their computers they still tend to perceive that using computer technology is easy. From the descriptive analysis data it can be seen that the low level of government support (19\%) does not affect the use of computer technology in respondents (50\% of respondents use computers). In addition, the rejection of $\mathrm{H} 3 \mathrm{a}$ can also be caused by a lack of specific applications being assessed so that leads to distortions to occur in respondents' judgments regarding the ease of use of computer technology. The variety of applications that are mastered and used by respondents can affect perceptions of ease. In this study, researchers do not control the applications used by respondents so that respondents may feel uncomfortable using the application X but find it easy to use application Y. These differences can affect the final results of respondents' perceptions.

In principle, what is proposed in testing the effect of insecurity on perception of technology is its negative effect on the perception of the ease and benefits of technology. The hypothesis proposed is H4a: Insecurity of technology negatively influences the perception of ease of use of technology, and $\mathrm{H} 4 \mathrm{~b}$ : Insecurity of technology negatively influences the perception of the benefits of using technology. Both hypotheses are submitted unsuccessfully supported. Test results on H4a show insignificant negative results, while $\mathrm{H} 4 \mathrm{~b}$ test results show contrasting results from the proposed 
hypothesis which shows positive and significant results. These results indicate that the phenomenon is in contrast to previous studies showing that insecurity variables have a negative influence on perceptions of technology [20] [21].

The differences in results occured because the previous studies' samples of technology adoption did not involve strong competition. Walczuch [20] used a sample of employees in the use of applications (technology) in a company that had no effect on one's achievements, while Ling and Moi [21] used students to find out readiness in adopting e-learning. The two conditions do not have an element of competition which requires the use of technology to win the competition. In contrast to previous research, this study uses a sample of business units aiming to make a profit. The achievement of profit is the main goal of the respondents of this study. Thus, even if an innovation (including technology) is risky (insecure), it will still be adopted as long as the innovation is considered beneficial.

The effect of perceived ease of use of technology on perceived usefulness was tested using the H5 hypothesis, namely perceived ease of use of technology had a positive effect on perceived usefulness of technology. The test results shows a positive and significant effect between the two variables. This reinforces previous research showing similar results. The ease and benefits of using technology have been widely validated by research after that. This study helped strengthen the evidence of the relationship between the constructs of the two variables [11].

Perception of ease and benefit of a technology has been proven by many previous researchers. The logic of the relationship between ease and benefit of interest in using IT can be said to be a common construct in various concepts of scientific disciplines. To examine the effect of perception on interest in using technology, this study proposes two hypotheses, namely: H6a: Perceived ease of use of technology has positive effect on the interest in using technology, and H6b: Perception of the benefits of using technology has a positive effect on interest in using technology. The test results shows that all the constructs tested show a positive and significant relationship. This result is in line with research conducted by [11] [22].

\section{Conclusions}

From the results of the test and discussion the following conclusions can be drawn:

In general, the research findings indicate that the furniture sector SMEs in Java are prepared to adopt IT. However, research findings also indicate that the perception of discomfort and insecurity is the major issue that potentially hinders the IT adoption by the furniture sector SMEs. The mentioned computer technology does not refer to a particular application, so that it strengthens the weaknesses of the questionnaire method that is self-report and can distort respondents' perceptions of an issue. This research does not pay attention/distinguish the size and complexity of the respondent's business.

\section{References}

[1] M. Rosemann and M. Zur Muehlen, "Evaluation of Workflow Management Systems - A Meta Model Approach," Australas. J. Inf. Syst., vol. 6, no. 1, pp. 1-20, 1998, doi: 10.3127/ajis.v6i1.322.

[2] Q. T. Pham, "Measuring the ICT maturity of SMEs," J. Knowl. Manag. Pract., vol. 11, no. 1.

[3] "Fullpaper Phuket-OSCM-2016-Mahendrawathi ER dkk." .

[4] Y. R. Suci, "Perkembangan UMKM (Usaha Mikro Kecil dan Menengah) di Indonesia," J. Ilm. Cano Ekon., vol. 6, no. 1, pp. 51-58, 2017.

[5] M. A. Nugroho, "Impact of Government Support and Competitor Pressure on the Readiness of SMEs in Indonesia in Adopting the Information Technology," Procedia Comput. Sci., vol. 72, pp. 102-111, 2015.

[6] C. Faller and D. Feldmüller, "Industry 4.0 Learning Factory for regional SMEs," Procedia CIRP, vol. 32, pp. 88-91, 2015.

[7] M. G. Aboelmaged, "Predicting e-readiness at Firm Level: An Analysis of Technological, Organizational, and Enviromental (TOE) Effects on e maintenance Readiness in Manufacturing Firms," Int. J. Inf. Manage., vol. 34, no. 5, pp. 639-651. 
[8] J. Y. L. Thong, "An integrated model of information systems adoption in small businesses," $J$. Manag. Inf. Syst., vol. 15, no. 4, pp. 187-214, 1999, doi: 10.1080/07421222.1999.11518227.

[9] A. Parasuraman and C.L. Colby, Techno-Ready Marketing: How and Why Your Customers Adopt Technology. New York: Free Press, 2001.

[10] Fred D. Davis, "A Technology acceptance model for empirically testing new-end user information systems: Theory and Result," Unpublished Ph.D. Dissertation, Sloan: Sloan School of Management, Massachusetss Institur of Technology (MIT)., 1986.

[11] F. D. Davis, "Perceived Usefulness, Perceived Ease of Use, and User Acceptance of Information Technology," MIS Q. Manag. Inf. Syst., vol. 13, no. 5, pp. 319-339, 1989.

[12] Fred D. Davis, Richard Bagozzi, and Paul R. Warshaw, "User Acceptance of Computer Technology: A Comparison of Two Theoretical Models," Manage. Sci., vol. 35, no. 8, pp. 982-1003.

[13] ICEK AJZEN, "From Intentions to Be havior: A Theory o f Planned Behavior," J. Kuhl and J. Beckman (Eds.), 1985, pp. 11-39.

[14] ICEK AJZEN, "The Theory of Planned Behavior," Organ. Behav. Hum. Decis. Process., vol. 50, pp. 179-211, 1991.

[15] Viswanath Venkatesh, Michael G. Morris, Gordon B. Davis, and Fred D. Davis, "User Acceptance of Information Technology: Toward a Unified View," Manag. Inf. Syst. Q., vol. 27, no. 3, pp. 425-478, 2003.

[16] E.M. Rogers, The Diffusion of Innovations. New York: Free Press, 1995.

[17] L. G. Tornatzky and M. Fleischer, The Process of Technological Innovation. Lexington, MA.: Lexington Books, 1990.

[18] Sugiyono, Belajar Analisis Data Sampel. Bandung: Alfabeta, 2010.

[19] W. Abdillah and J. Hartono, Partial Least Square (PLS) Alternatif Structural Equation Modelling (SEM) dalam Penelitian Bisnis. Yogyakarta: Penerbit ANDI, 2015.

[20] Rita Walczuch, Jos Lemmink, and Sandra Streukens, "The effect of service employees' technology readiness on technology acceptance," Inf. Manag., vol. 44, pp. 206-215, 2007.

[21] Lai Ming Ling And Chong Moi Moi, "Professional Students' Technology Readiness, Prior Computing Experience And Acceptance Of An E-Learning System," Malaysian Account. Rev., vol. 6, no. 1, pp. 85-99, 2007.

[22] William Lewis Jr., Ritu Agarwal, and Vallabh Sambamurthy, "Sources of Influence on Beliefs about Information Technolgoy Use: An Empirical Study of Knowledge Workers," MIS $Q$. Manag. Inf. Syst., vol. 27, no. 4, pp. 657-678. 